Sessions d'étude - Société canadienne d'histoire de l'Église catholique

\title{
Autre communication
}

\section{Les églises de La Prairie, reflets d'une société?}

\section{Gaétan Bourdages}

Volume 51, 1984

URI : https://id.erudit.org/iderudit/1007454ar

DOI : https://doi.org/10.7202/1007454ar

Aller au sommaire du numéro

Éditeur(s)

Les Éditions Historia Ecclesiæ Catholicæ Canadensis Inc.

ISSN

0318-6172 (imprimé)

1927-7067 (numérique)

Découvrir la revue

Citer ce document

Bourdages, G. (1984). Autre communication : les églises de La Prairie, reflets d'une société? Sessions d'étude - Société canadienne d'histoire de l'Église catholique, 51, 87-87. https://doi.org/10.7202/1007454ar

Tous droits réservés @ Les Éditions Historia Ecclesiæ Catholicæ Canadensis Inc., 1984
Ce document est protégé par la loi sur le droit d'auteur. L'utilisation des services d'Érudit (y compris la reproduction) est assujettie à sa politique d'utilisation que vous pouvez consulter en ligne.

https://apropos.erudit.org/fr/usagers/politique-dutilisation/ 


\title{
Autre communication
}

\author{
Gaétan BouRdaGes \\ Les églises de La Prairie, \\ reflets d'une société?
}

\begin{abstract}
À partir du dépouillement systématique de tous les achats effectués par la fabrique de La Prairie entre 1686 et 1886, Gaétan Bourdages tente d'établir un parallèle entre les dépenses de la paroisse et la situation économique qui prévalait à La Prairie de 1668 à 1846. Les pièces examinées concernent la construction et la réfection de l'église et du presbytère, ainsi que les achats de mobilier, objets de culte, etc. Il semble d'après l'étude qu'on ne puisse établir de corrélation entre la situation économique et les dépenses de la fabrique. Contrairement à ce qu'on aurait pu penser, les dépenses sont importantes en période difficile, alors qu'elles apparaissent relativement modérées en période d'abondance.
\end{abstract}

